УДК 549.32/.33:553.412'44

\title{
МИНЕРАЛОГИЯ БАРИТ-ПОЛИМЕТАЛЛИЧЕСКИХ МЕСТОРОЖДЕНИЙ ЗМЕИНОГОРСКОГО РУДНОГО РАЙОНА (РУДНЫЙ АЛТАЙ)
}

\author{
Бестемьянова Ксения Викторовна ${ }^{1}$, \\ KsenijaVT@mail.ru \\ Гринев Олег Михайлович1, \\ tomskgrom@yandex.ru \\ 1 Национальный исследовательский Томский государственный университет, \\ Россия, 634050, г. Томск, пр. Ленина, 36.
}

\begin{abstract}
Актуальность исследования обусловлена пониманием важности разработки современной генетической модели изучаемых месторождений, что в свою очередь ведет к разработке научно-обоснованных прогноза и оценки объектов и в итоге расширению минерально-сырьевой базы для воспроизводства запасов полиметаллических руд, прежде всего, меди свинца и цинка, с учетом продолжающихся поисково-разведочных работ на Рудном Алтае, в том числе на фрлангах и глубоких горизонтах уже известных месторождений.

Цель: изучение минерального состава руд с использованием современных методов исследования вещества, выявление минералого-геохимических характеристик, а также ряда генетических аспектов образования барит-полиметаллических руд месторождений Змеиногорского рудного района.

Методы. Проведено комплексное исследование барит-полиметаллических руд, включающее характеристику минерализации в поляризационном микроскопе, исследование руд и отдельных сульфидных минералов рентгеновским энерго-дисперсионным микроанализом, масс спектрометрическим с индуктивно связанной плазмой (ICP-MS), атомно-абсорбционным, а также массспектрометрическим изотопным анализом.

Результаты. Изучена минералогия руд барит-полиметаллических месторождений Змеиногорского рудного района, насчитывающая порядка 30 минералов, среди которых, в порядке убывания, отмечены: сульфиды, сульфасоли, теллуриды, окислы, соли кислородных кислот, самородные элементы и интерметаллические соединения. Выделены основные минеральные парагенезисы, соответствующие последовательным стадиям минералообразования (рудной составляющей): пирит-сфралеритхалькопиритовая ассоциация, отвечающая первой стадии минералообразования; галенит-блекловорудная ассоциация (вторая стадия); борнит-халькозиновая ассоциация (третья стадия); барит-кальцит-гематитовая ассоциация (четвертая стадия). Изучен химический состав основных и примесных компонентов в сульфидах, выявлены ранее не диагностированные минералы. Установлена наиболее продуктивная на выделение самостоятельных минеральных фраз благородных металлов третья стадия (борнит-халькозиновый парагенезис). Источник вещества в процессе рудообразования имел гетерогенньй характер, который обусловлен мантийными изотопными метками при начальных стадиях и сменой их на коровые, вариации изотопных характеристик ( $\delta^{34}$ S) сульфридов первой стадии $-0,2 \ldots+1,2 \% ;$ сульфидов второй стадии $-2,3 . . .-3,7 \%$; сульфридов третьей стадии $-8,9 . . .-12,8 \%$.
\end{abstract}

\section{Ключевые слова:}

Змеиногорский рудный район, барит-полиметаллические руды, стадийность, парагенетические ассоциации, изотопы серы.

\section{Введение}

Рудный Алтай по своему статусу и значению является одним из богатейших на полезные ископаемые регионов России. Особое место, в первую очередь, отводится на полиметаллы $(\mathrm{Cu}, \mathrm{Pb}, \mathrm{Zn})$, на долю которых приходится $10 \ldots 15 \%$ от общего числа извлекаемых на территории Российской Федерации, при этом одним из основных геолого-промышленных типов месторождений является семейство колчеданных месторождений [1]. В одном только Змеиногорском рудном районе за 2020 г. добыто 905203 тыс. т полиметаллических руд, в общероссийском масштабе Алтайский край занимает шестое место по добыче полиметаллических руд, которые представлены VMS типом (34 \% всех полиметаллических месторождений РФ) [2], образовавшихся в наиболее продуктивную неопротерозойско-палеозойскую эпоху [3].

Основными типами добываемых в регионе руд являются колчеданно-полиметаллические и баритполиметаллические руды. Наиболее богатым по количеству месторождений является Змеиногорский рудный район. В нем выделяется более 10 месторож- дений, рудопроявлений, а также множество пунктов минерализации, относящихся к колчеданнополиметаллической субформации.

Основные прогнозно-металлогенические исследования в пределах рудного района проводились в 1960-1963 гг. В это время геологами Рудно-Алтайской экспедиции составлена прогнозная карта Змеиногорского и Золотушинского рудных районов в масштабе 1:200000 [4], в дальнейшем детальные работы с выявлением перспективных рудных зон, установлением детальных схем стратиграфии и магматизма района были проведены в 1970-1976 гг. Однако в историческом аспекте использование недр региона уходит в глубокую древность, к периоду энеолита (ранней бронзы), когда легендарные племена «Чуди» из выходящих на дневную поверхность окисленных полиметаллических руд извлекали медь, свинец, золото, серебро [5].

Минералогия барит-полиметаллических объектов изучена на примере трех месторождений, непосредственно Змеиногорского, Зареченского и Стрижковского, располагающихся в пределах одноименного Змеиногорско-Зареченского рудного поля. Объекты 
имеют сложное геологическое строение и более богатое минералогическое разнообразие по сравнению с месторождениями колчеданно-полиметаллической субформации. По данным предшественников [6] на изученных месторождениях выделяется около 30 минералов, среди которых основная часть отводится сульфидам, в меньших количествах присутствуют сульфосоли, самородные элементы, еще реже встречаются теллуриды и интерметаллические соединения.

Зареченское месторождение является действующим, эксплуатируемым объектом, Стрижковское месторождение входит в категорию законсервированных, Змеиногорское считается отработанным, однако в ходе очередных разведочных работ (начало 1990-х гг.) подтверждено наличие нескольких рудных тел, залегающих на глубоких горизонтах.

\section{Объекты исследования}

Выбранные для изучения месторождения - Змеиногорское, Зареченское, Стрижковское, находятся в непосредственной близости друг от друга (4...5 км), в структурном плане приурочены к прибортовой северовосточной части Змеиногорско-Быструшинского прогиба, относящегося в региональном плане к северовосточному флангу Рудно-Алтайского мегапрогиба. Развитие оруденения контролируется локальными вулканотектоническими структурами, положение которых приурочено к узлам пересечения поперечных разломов и продольных межблоковых структур [7]. Согласно новым данным, барит-полиметаллическое оруденение района контролируется довольно крупной Рудничной вулканотектонической структурой раннедевонского возраста заложения, а в ее пределах - разломной решеткой, образуемой субширотными (продольными) и северсеверо-западными (поперечными) разломами, относительно простирания Змеиногорского прогиба [8].

В масштабах рудных полей месторождения обычно приурочены к бортам вулкано-тектонических депрессий, локализуясь в пределах вулканических аппаратов или в непосредственной близости от них [9].

В течение девона на территории прогиба проявлялись процессы вулканизма, носящие эпизодический характер [10], с которым связано образование базальт-риолитовой формации. При этом эволюция вулканизма на территории Рудного Алтая имела антидромную направленность. Антидромная природа развития магматизма обусловила специфическую металлогению региона, выразившуюся сменой баритполиметаллических и полиметаллических месторождений на эмско-эйфельском этапе, колчеданнополиметаллическими на живетско-раннефранском этапе и затем колчеданными на позднефранскораннефаменском этапе [11].

В геологическом строении месторождений (рис. 1) принимают участие вулканогенно-осадочные породы нижнего девона, залегающие на палеозойском зеленокаменном фундаменте, представленном метаморфитами, смятыми в разнопорядковые складки до плойчатых, породами корбалихинской толщи, датированной O-S 1 возрастом U-Pb методом по цирконам и $\mathrm{Ar}^{40} / \mathrm{Ar}^{39}$ по серициту.
Рудовмещающий нижнедевонский разрез представлен залегающими практически моноклинально переслаивающимися алевролитами, песчаниками, туфами основного и преимущественно кислого состава и известняками, слагающими нижнемельничную подсвиту $\left(\mathrm{D}_{1} m n\right)$. В структуре рудных полей месторождений отмечаются многочисленные дайки габброплагиогранит-лейкогранитового Змеиногорского комплекса $\left(\mathrm{D}_{3} \mathrm{Z}_{1-4}\right)$.

Месторождения локализуются в зонах пересечения субмеридиональных и субширотных разломов и зон трещиноватости, рассекающих ранне-среднедевонские толщи. Рудные тела представляют усложненные лин30-, ленто- и штокверкообразные формы, с мощностью в пределах от 0,5 до 20 м. Рудные тела приурочены к зонам срыва, рассланцевания и отслаивания на контактах туфов кислого состава, хрупких кремнистых пород с известняками, известковистыми аргиллитами, к зонам дробления кремнистых пород, реже кремнистых аргиллитов, алевролитов, и известняков. Реже оруденение отмечается в зонах межпластового и внутрипластового рассланцевания пород, еще реже в зонах дробления и рассланцевания, сопровождающихся крупными разломами. На изученных месторождениях распространением пользуются следующие типы руд: колчеданно-полиметаллические, полиметаллические (среди которых выделяются существенно медно-свинцовые и свинцово-цинковые) и барит-полиметаллические. Тела данных типов руд последовательно, кулисно сменяют друг друга вверх по разрезу.

Схожая зональность характерна не только для колчеданных месторождений Рудного Алтая, но и для других объектов такой же формационной принадлежности и генезиса, например уральского региона [12] или Салаирской области [13], однако в общем металлогеническом плане, как отмечается исследователями [14], Рудный Алтай имеет полиметаллическую направленность оруденения, в то время как Урал, а именно его южная часть, существенно медноцинковую.

Характерные структуры изученных руд: кристаллически-зернистая, неравномернозернистая, мелко-, средне-, редко крупнозернистая, гипидио- и аллотриоморфнозернистая, эмульсионная, дробления, замещения, колломорфная, смятия. Характерные текстуры руд: вкрапленная, прожилковая, прожилкововкрапленная, гнездовая, массивная.

Рудные тела всех изученных месторождений сопровождаются значительными околорудными изменениями, которые представлены породами, относящимися к бескарбонатной фации березитов и характеризующимися кварц-серицитовым, кварц-хлорит-серицитовым и кварц-хлоритовым составом. Эти раннедевонские дорудные породы являются продуктами, которые были сформированы в результате воздействия углекислотных растворов на вмещающие слаболитифицированные нижнедевонские вулканогенно-осадочные породы, преимущественно туфы кислого состава. Зоны их развития, как и сами руды, контролируются субширотными и субмеридиональными разрывными нарушениями, а также зонами рассланцевания [15] 
(a)
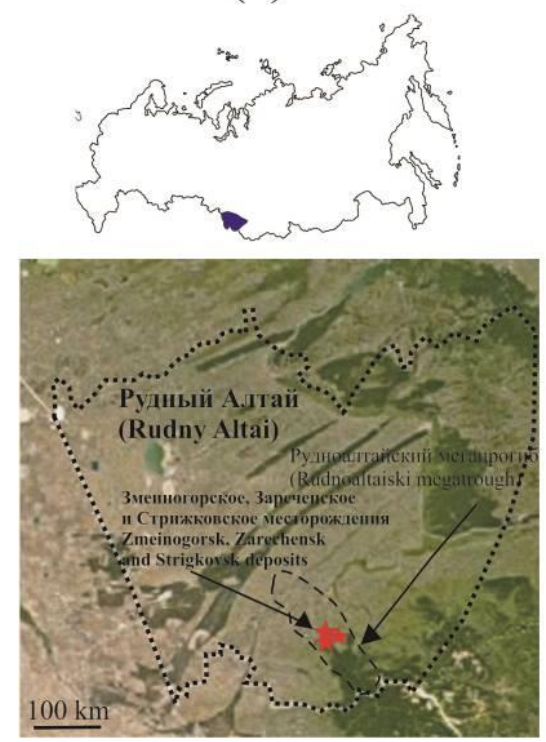

(b)

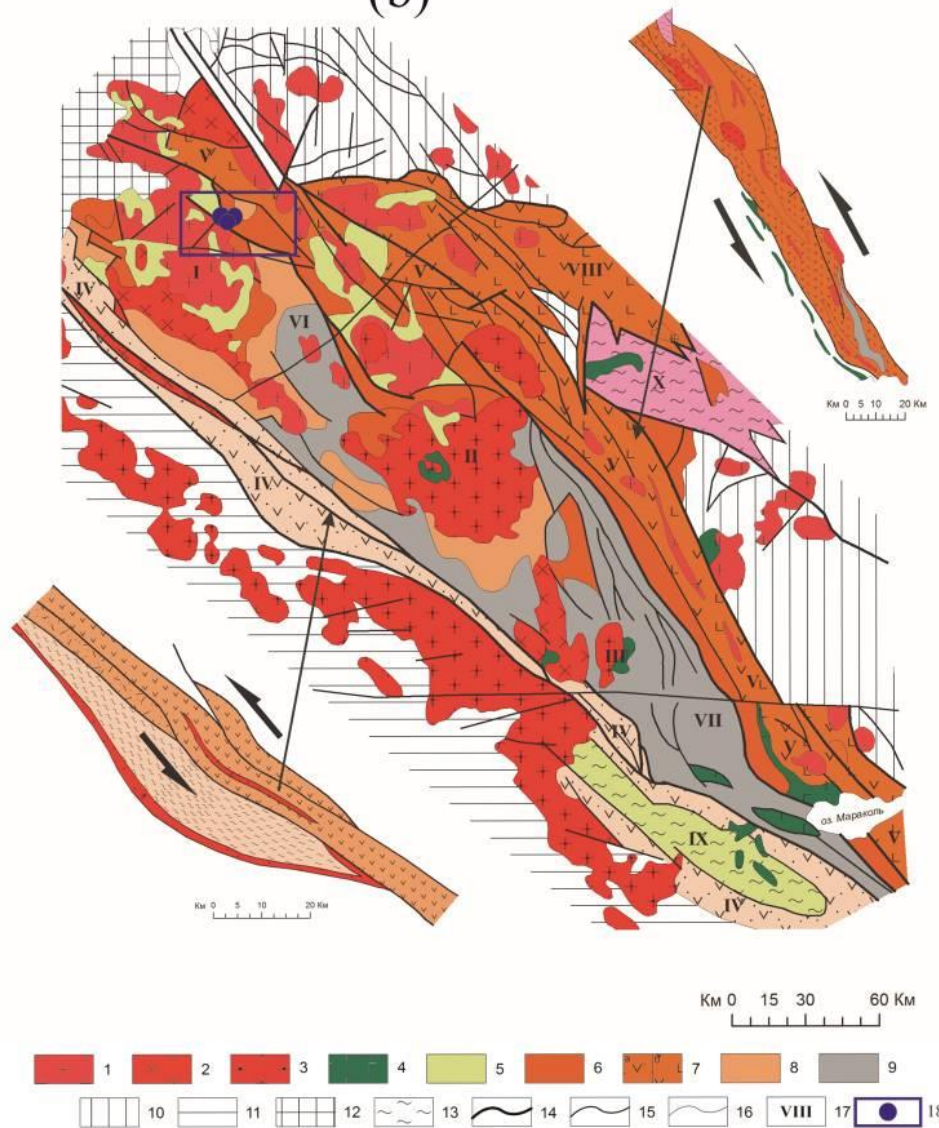

Puc. 1. Обзорная карта (Google Earth) расположения Змеиногорского рудного района (a) и схематическая карта геологического строения Рудноалтайского мегапрогиба с местоположением Змеиногорского рудного района и месторождений (b) [8]. 1 - девонские и додевонские (?) гранитоиды змеиногорского комплекса; 2 - карбоновые гранитоиды алейского комплекса; 3 - раннепермские гранитоиды калбинского комплекса; 4 - интрузии основного состава нерасчлененные (D, C, P); 5 - метаморфические комплексы $(O-S$ ?); 6 - нерасчлененные толщи; 7 - толщчи прибортовых депрессионных зон: а) средне-верхнедевонские и б) ранне-средневерхнедевонские; 8 - толщи среднего-верхнего девонабыструшинского и белоубинского синклинориев; 9 - толщи верхнего девона - нижнего карбона Калба-Нарымской СФ3; 10 - байкалиды и каледониды Горного Алтая; 11 - Калба-Нарымская СФ3; 12 - Барнаульская впадина; 13 - динамометаморфические образования выступов основания $\left(R-C_{1}\right) ; 14$ - шовные зоны 1-го порядка; 15 - разрывные нарушения; 16 - границы структурно-вещественных комплексов; 17 - основные морфоструктурные элементы: I - Алейский гранитнометаморфический свод (ГМС); II - Синюшинский свод; III - Соловьёвский свод; IV - ЗолотушинскоИртышско-Курчумская прибортовая депрессионная зона, приуроченная к Иртышской зоне смятия; $V-3 м е-$ иногорско-Белоубинско-Маркакольская прибортовая депрессионная зона, приуроченная к северо-восточной зоне смятия, VI - Быструшинский синклинорий; VII - Белоубинский синклинорий; VIII - Коргонский грабенообразный прогиб; IX - Курчумский выступ динамометаморфитов докембрия (?) - раннего палеозоя; $X-T e$ рехтинский выступ байкалид; 18 - Змеиногорский рудный район и Змеиногорское, Зареченское, Стрижковское барит-полиметаллические месторождения

Fig. 1. Overview map (Google Earth) of location of the Zmeinogorsk ore district (a) and a schematic map of the geological structure of Rudnoaltaisk megatrough with location of Zmeinogorsk district and ore deposits $(b) .1$ - Devonian and Predevonian (?) Zmeinogorsk complex granitoids; 2 - Carboniferous Aleysk complex granitoids, 3 - early Permian Kalbinsky complex granitoids; 4 - unsubdivided mafic intrusions $(D, C, P) ; 5$ - metamorphic complexes $(O-S$ ?); 6 - unsubdivided strata; 7 - boundary depression zones strata: a) middle and upper Devonian and b) lower, middle and upper Devonian; 8 - middle and upper Devonian Bystrushinsky and Beloubinsky synclinorium strata; 9 - upper Devonian and lower Carboniferous Kalba-Narym zone strata; 10 - Altai Baikalides and Caledonides; 11 - KalbaNarym zone; 12 - Barnaul sag; 13 - dynamometamorphic rocks of basement highs $\left(R-C_{1}\right) ; 14$ - first-order suture zones; 15 -disjunctive faults; 16 - structural-compositional complexes boundaries; 17 - main morphostructure elements: I - Aleysk granite-metamorphic anticline (GMA); II - Sinyuschinsk anticline; III - Solovyevsk anticline; $I V$-Zolotushinsk-Irtush-Kurchumsk near edge depression zone, confinedness to Irtysh shear zone; V-ZmeinogorskBeloubinsk-Markakolsk near edge depression zone, confinedness to north-earth shear zone, VI-Bystrushinsk synclinore; VII - Beloubinsk synclinore; VIII - Korgonski keystone fault trough; IX - Kurchumsk outshot of precembrian dynamomorphics (?) - early Paleozoic; X - Terekhtinsk outshot of baikalides; 18 - Zmeinogorsk ore region and Zarechensk, Zmeinogorsk, Strigkovsk barite-polymetallic deposits 
Мощность таких зон околорудного изменения составляет $15 \ldots 130$ м. Основными породообразующими минералами околорудноизмененных пород являются: кварц, серицит, хлорит; второстепенными - пирит; редкими - апатит, циркон, рутил, халькопирит, сфалерит, галенит, барит, также в минеральном составе околорудноизменных пород выявлено наличие редкоземельной минерализации, представленной игольчатыми зернами монацита и ксенотима. Данные породы играют индикаторную роль в формировании развития барит-полиметаллических руд и могут косвенно указывать на наличие скрытого оруденения.

Минеральный состав руд месторождений довольно схожий со многими объектами такой же субформации, располагающимися не только на территории Российской Федерации, но и, например, в объектах, находящихся на территории Турции [16], Италии [17] Канады [18]. Главными минералами руд являются: пирит, сфалерит, халькопирит, галенит; второстепенными - блеклые руды, борнит, халькозин; редкими алтаит, штромейерит, гессит, ялпаит, аргентит (акантит), самородное серебро, электрум, амальгамы золота и серебра. Нерудные минералы - барит, кварц, в меньшей степени кальцит. Наиболее сложным по минеральному составу является Зареченское месторождение, на котором насчитывается около 40 минеральных видов, самым простым по составу считается Стрижковское месторождение.

В качестве примесных в рудах фиксируется широкий комплекс элементов, среди которых $\mathrm{Sc}, \mathrm{Ti}, \mathrm{V}, \mathrm{Co}$, $\mathrm{As}, \mathrm{Se}, \mathrm{Rb}, \mathrm{Sr}, \mathrm{Cd}, \mathrm{Sb}, \mathrm{Te}, \mathrm{Tl}, \mathrm{Bi}$. Концентрации данных элементов имеют несколько дифференцированное распределение в разных типах руд. При этом такие элементы, как $\mathrm{Co}, \mathrm{As}, \mathrm{Sb}, \mathrm{Se} \mathrm{Bi,} \mathrm{являются} \mathrm{типо-}$ морфными для объектов данного генезиса [19].

\section{Методы исследования}

Характеристика рудной минерализации в аншлифах и плоскопараллельных пластинках (160 образцов) проводилась на поляризационном микроскопе Leica DM 750P (аналитик К.В. Бестемьянова). В первую очередь внимание уделялось онтогеническим характеристикам, а также характеру взаимоотношения между минеральными видами.

Анализ вещественного состава рудных минералов, а также качественные изображения характера взаимоотношения минеральных ассоциаций и минеральных индивидов в режиме обратно рассеянных электронов (режим BSE) проводился методом рентгеноспектрального микроанализа (805 определений, по 2-3 определения на зерно, из них 201 определение сульфидов Змеиногорского месторождения, 278 определений на Стрижковском месторождении, 326 определений на Зареченском месторождение) на электронном сканирующем микроскопе Tescan Vega II LMU (Чехия, TESCAN), оборудованном энергодисперссионным спектрометром (с детектором $\mathrm{Si}(\mathrm{Li})$ Standart) INCA Energy 350 (аналитик К.В. Бестемьянова). Для этого из отобранных образцов основных типов руд были изготовлены плоскопараллельные аншлифы толщиной $3 \ldots 4$ мм. Перед проведением аналитических работ на поверхность изучаемых образцов предварительно напылялся слой углерода толщиной $25 \ldots 30 \mathrm{HM}$, в соответствии с рекомендуемой методикой [20]. Ускоряющее напряжение для СЭМ съемки и анализа было 20 кВ с интенсивностью тока зонда в пределах 1,1...1,4 нА. Локальный рентгено-спектральный микроанализ выполнялся с предварительной калибровкой интенсивности зонда по кобальтовому стандарту при рабочем (фокусном) расстоянии 15 мм. СЭМ фотографии накапливались преимущественно с использованием детектора обратнорассеянных электронов (BSE - backscattered electrons).

Содержания примесных компонентов в различных типах руд (36 порошковых проб, из них 8 проб руд Змеиногорского месторождения, 12 проб руд Стрижковского месторождения, 16 проб руд Зареченского месторождения) определялись методом ICP-MS (масс-спектрометрия с индуктивно связанной плазмой) на приборе Agilent 7500 x (Agilent Technologies, США), аналитик Е.С. Рабцевич.

Аналитика методами рентгеноспектрального микроанализа и ICP-MS выполнена в центре коллективного пользования «Аналитический центр геохимии природных систем» (НИ ТГУ, г. Томск).

Содержания золота и серебра в 36 пробах основных типов руд (из них 8 проб Змеиногорского месторождения, 12 проб Стрижковского месторождения, 16 проб Зареченского месторождения) определялись атомно-абсорбционным методом (аналитик В.Н. Ильина) на атомно-абсорбционном спектрофотометре Solaar M6 (чувствительность анализа $1 \cdot 10^{-8}$ мас. \%) в аналитическом центре «Центр коллективного пользования научным оборудованием много-элементных и изотопных исследований СО РАН» института Геологии и Минералогии им. В.С. Соболева Сибирского отделения Российской Академии наук (г. Новосибирск).

Вариации изотопного состава серы сульфидных минералов (36 монофракций сульфидов, из которых 10 отобраны из образцов Змеиногорского месторождения, 12 из образцов Стрижковского месторождения, 14 проб из образцов Зареченского месторождения) определялись в центре ДВГИ ДВО РАН (г. Владивосток) в лаборатории стабильных изотопов, измерение изотопных соотношений серы проведено на изотопном масс-спектрометре Finnigan MAT 253 (ThermoFinnigan, Bremen, Germany) с использованием двойной системы напуска (аналитик Т.А. Веливецкая).

\section{Результаты и их обсуждение}

Процесс рудообразования изученных месторождений имел полистадийный характер, что свойственно многим объектам гидротермального генезиса [21]. При изучении были выделены основные минеральные парагенезисы, соответствующие стадиям рудообразования, последовательно сменяющим друг друга, от начала процесса к его завершению.

Пирит-сфалерит-халькопиритовая парагенетическая ассоциация (1 стадия минералообразования). Характерные структуры и текстуры для данной ассоциации: текстуры: вкрапленная, прожилковая, реже 
брекчиевидная; структуры: тонко-, мелко-, среднезернистая, идиоморфная, аллотриоморфнозернстая, коррозионная, эмульсиевидная.

Пирит I в данной ассоциации представлен тонкои мелкозернистыми массами (рис. 2, a), которые образуют идиоморфные зерна размером $0,1 \ldots 3$ мм кубического, пентагондодекаэдрического габитуса, а также комбинацией куба и октаэдра (указано в порядке распространения). Такие обособления пирита зачастую деформированы, разбиты сетью трещин, фрагменты зерен часто растащены и с признаками замещения более поздними сульфидами. Встречается как в колчеданно-полиметаллическом типе руд, так и в существенно полиметаллическом.
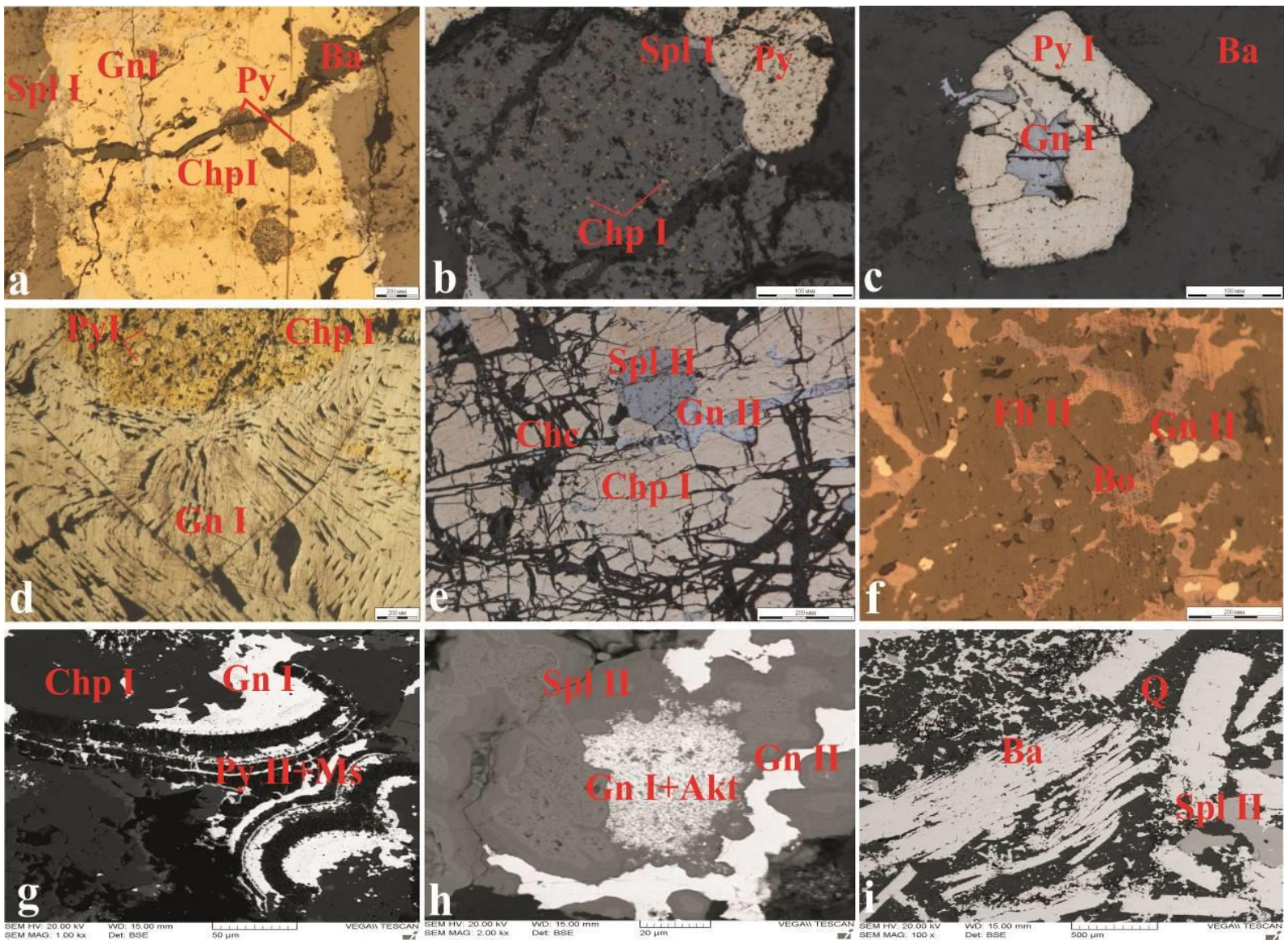

Рис. 2. Основные микро-структурно-текстурные характеристики руд барит-полиметаллических месторождений Змеиногорского рудного района: а) тонкозернистые обособления пирита, сцементированные халькопиритом и разбитые сетью трещин более позднего барита (полиметаллический тип руд); b) эмульсионная вкрапленность халькопирита в сфалерите; с) замещение пирита галенитом I; d) проявление структуры деформации в галените, искривленные треугольники выкрашивания по спайности, возникшие в результате деформации; е) петельчатая структура, образованная замещением халькопирита I халькозином, в прожилках галенит II и сфалерит II; f) обособления борнита и халькозина в агрегате блеклой руды (борнит-халькозиновая парагенетическая ассоииация); g) фрагменты зональных почек более позднего пирита-марказита (из существенно полиметаллического типа руд); h) прожилки галенита II между агрегатами сфалерита II (с проявленной осиилляторной зональностью) и обособление галенита I с редкими включениями акантита; i) расмепленные столбчатые кристалль барита, сцементированные кварчем, в интерстичиях агрегаты сфалерита II (барит-полиметаллический тип руд). Примечание: Py - пирит, Spl - cфалерит, Chp - халькопирит, Gn - гале-

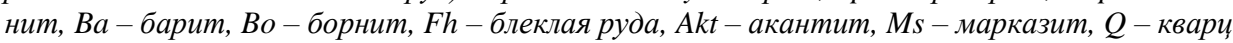

Fig. 2. Basic micro-structure-texture characteristics of ores of barite-polymetallic deposits of Zmeinogorsk ore district: a) fine-grained pyrite segregations cemented by chalcopyrite and broken by a network of cracks of later barite (polymetallic ores type); b) emulsion structure of decomposition of chalcopyrite solid solution in sphalerite; c) replacement of pyrite I with galena I; d) occurrence of crumpling structure in galena, curved triangles of spalling along cleavage resulting of deformation; e) reticulate structure, formed by chalcopyrite I replacement with chalcocite, in veins galena II and sphalerite II; f) bornite and chalcocite segregation in a fahlore unit (bornite-chalcocite paragenetic association); g) fragments of zonal buds of later pyrite-marcasite (from an essentially polymetallic ores type ); h) veinlets of galena II, between aggregates of sphalerite II (with pronounced oscillatory zoning), and segregation of galena I with rare acanthite inclusions; i) split columnar barite crystals, cemented by quartz, aggregates of sphalerite II in the interstices (barite-polymetallic ores). Notice: Py-pyrite, Spl-sphalerite, Chp - chalcopyrite, Gn-galena, Ba-barite, Bo-bornite, Fh-fahlore, Akt-akantite, Ms-marcasite, $Q$-quartz 
Сфалерит I в виде сплошных зернистых масс или отдельных зерен размером $0,05 \ldots 10$ мм слабоокрашенных или практически бесцветных, с хорошо проявленной спайностью. Наибольшим распространением пользуется в колчеданно-полиметаллических и полиметаллических типах руд. Очень часто в сфалерите данной ассоциации отмечается эмульсионная вкрапленность халькопирита (рис. 2, b), образуя структуру распада твердого раствора, при этом при исследовании газово-жидких включений в сфалерите данной ассоциации, которые в свою очередь являются трехфазными (жидкость-газ+твердая фаза), в качестве твердой фазы отмечены тетраэдрические кристаллики халькопирита. В качестве изоморфной примеси сфалерит I обнаруживает примесь железа до 2,2 мас. $\%$.

Халькопирит нередко выполняет пространство между ранее выделившимися зернами и агрегатами пирита, зачастую цементируя их раздробленные фрагменты. Также образует прожилки, линзочки, между обособленными зернами и агрегатами сфалерита. Наибольшим распространением пользуется в колчеданно-полиметаллическом типе, а также в существенно полиметаллическом, редкие единичные зернистые агрегаты отмечены в баритполиметаллическом типе руд. На Стрижковском месторождении слагает гнезда зернистых агрегатов размером $0,5 \ldots 2$ см в существенно свинцовом типе руд (практически мономинеральные галенитовые руды), а также совершенно незначительные по распростране- нию вкрапленные медные руды в палеозойской зеленосланцевой толще (корбалихинская свита $\mathrm{O}-\mathrm{S}_{1} \mathrm{kr}$ ). Халькопирит довольно часто замещается более поздними минералами, например халькозином, в меньше степени борнитом (рис. 2, e).

Галенит-блекловорудная парагенетическая ассоииация (2 стадия минералообразования).

Галенит формирует прожилки, гнезда и неправильной формы обособления, встречается в полиметаллическом типе руд, а также баритполиметаллическом. Образует неровные, зазубренные и заливообразные границы с ранее выделившимися сульфидами. Как уже было сказано выше, на Стрижковском месторождении образует практически мономинеральные свинцовые руды, преимущественно средне-, реже крупнозернистой структуры, с редкими включениями единичных зерен сфалерита I и халькопирита I. Довольно часто наблюдается замещение галенитом ранее выделившихся сульфидов, например, пирита (рис. 2, c). Также довольно часто на всех изученных месторождениях в зернах и агрегатах галенита отмечаются признаки деформации, в виду хорошей его пластичности, как правило, это искривленные треугольники выкрашивания по спайности минерала (рис. $2, d$ ), что говорит о проявлении син- и пострудной тектоники.

Довольно часто в галените данной ассоциации отмечается примесь селена (особенно на Стрижковском и Зареченском месторождениях), до 1,2 мас. \% (табл. 1).

Таблица 1. Средний химический состав сульфидов выделенных парагенетических ассоциаций барит-полиметаллических Змеиногорского, Зареченского, Стрижковского месторождений Змеиногорского рудного района

Table 1. Average chemical sulfides composition of subtracted paragenetic association of barite-polymetallic Zmeinogorsk, Zarechensk, Strigkovsk deposits of Zmeinogorsk ore district

\begin{tabular}{|c|c|c|c|c|c|c|c|c|c|c|c|c|}
\hline \multirow{2}{*}{$\begin{array}{l}\text { Минерал } \\
\text { Mineral }\end{array}$} & \multirow{2}{*}{$\begin{array}{c}\text { Количество определений } \\
\text { Number of points }\end{array}$} & \multicolumn{11}{|c|}{ Элементы, мас. \%/Elements, wt. \% } \\
\hline & & $\mathrm{S}$ & $\mathrm{Fe}$ & $\mathrm{Cu}$ & $\mathrm{Zn}$ & As & $\mathrm{Se}$ & $\mathrm{Ag}$ & $\mathrm{Cd}$ & $\mathrm{Sb}$ & $\mathrm{Pb}$ & $\begin{array}{c}\text { Сумма } \\
\text { Sum }\end{array}$ \\
\hline \multicolumn{13}{|c|}{ Сульфиды I стадии/Sulfides of the first stage } \\
\hline Пирит/Pyrite & 69 & 52,8 & 46,8 & - & \begin{tabular}{|c}
- \\
\end{tabular} & - & - & - & - & - & - & 99,6 \\
\hline X/пирит/Chalcopyrite & 81 & 34,26 & 29,7 & 35,1 & - & - & - & - & - & - & - & 99,06 \\
\hline Сфалерит I/Sphalerite I & 75 & 35,02 & 2,2 & - & 62,96 & - & - & - & - & - & - & 100,18 \\
\hline \multicolumn{13}{|c|}{ Сульфиды II стадии/Sulfides of the second stage } \\
\hline Сфалерит II/Sphalerite II & 87 & 34,27 & 0,20 & - & 64,12 & - & - & - & 1,5 & - & - & 100,09 \\
\hline Галенит I/Galena I & 90 & 13,23 & 0,72 & - & - & - & 1,2 & - & - & - & 85,20 & 100,35 \\
\hline Тетраэдрит/Tetrahedrite & 93 & 24,75 & 1,20 & 38,70 & 7,34 & 4,32 & - & $0 \ldots 12$ & - & 23,75 & 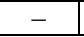 & 100,06 \\
\hline \multicolumn{13}{|c|}{ Сульфиды III стадии/Sulfides of the third stage } \\
\hline Борнит/Bornite & 68 & 25,51 & 11,36 & 62,86 & - & - & - & $0 \ldots 5$ & - & - & - & 99,73 \\
\hline Теннантит/Tennantite & 70 & 30,98 & 0,63 & 40,34 & 7,0 & 15,47 & - & $0 \ldots 2$ & - & 5,96 & - & 100,38 \\
\hline X/пирит II/Chalcopyrite II & 56 & 35,26 & 30,34 & 34,37 & 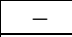 & - & - & - & - & - & - & 99,7 \\
\hline Халькозин/Chalcosine & 64 & 19,4 & - & 78,0 & - & - & - & 2,2 & - & - & - & 99,96 \\
\hline Галенит II/Galena II & 52 & 13,72 & - & - & - & - & - & 1,45 & - & - & 84,17 & 99,34 \\
\hline
\end{tabular}

Тетраэдрит распространен на всех изученных месторождениях в составе выделенной ассоциации. Отмечен в полиметаллическом типе руд, а также в барит-полиметаллическом. Образует в основном тонкои мелкозернистые агрегаты, реже отдельные зерна в тесном срастании с галенитом I и халькопиритом I. На Зареченском месторождении в некоторых рудных телах отмечаются участки, сложенные тетраэдритом, галенитом, сфалеритом и незначительной частью халькопирита, с ярко выраженными зеркалами скольжения, с абсолютно гладкой поверхностью, причем как минимум в двух-трех направлениях, что также говорит о проявлении интенсивных тектонических напряжений и «подвижек» в процессе рудообразования.

Интересным является тот факт, что в составе тетраэдрита на всех изученных месторождениях довольно устойчиво отмечается примесь серебра вплоть до 12 мас. \%. При этом наиболее богатым на содержание серебра является тетраэдрит Зареченского месторож- 
дения (0..12 мас. \%), несколько меньшие значения отмечаются в тетраэдрите Змеиногорского месторождения $(1,5 \ldots 9$ мас. \%), и самое меньшее количество отмечается в тетраэдрите Стрижковского месторождения $(0 \ldots .5$ мас. \%).

Для Зареченского и Змеиногорского месторождений наблюдается эволюция от ранних сурьмянистых разностей блеклой руды (тетраэдрит) к более поздней мышьяковистой разности блекловорудной изоморфной серии, вероятно, обусловленная изменением условий минералообразования, прежде всего изменением солености флюида и снижением температуры, что влияет и на степень миграции металлов.

Сфалерит II отмечен как в полиметаллическом типе руд, так и в барит-полиметаллическом, образует мелко- и среднезернистые агрегаты, в тесном срастании с галенитом и тетраэдритом. Участками в зернах сфалерита данной ассоциации отмечается осцилляторная зональность (рис. 2, h), связанная с процессами самоорганизации в системе, удаленной от равновесия, и кинетическими факторами роста минералов [22].

Иными словами, осцилляторная зональность обусловлена возникновением градиента концентраций (в данном случае примеси $\mathrm{Cd}$ до 1,5 мас. \%) на границе минерала и флюида, где имеет место обратная связь между отложением зон, богатых одним компонентом как результирующим фактором градиента диффузии на границе раздела кристалл и флюид и осаждением другого компонента [23]. Стоит отметить, что содержание кадмия в сфалеритах изученных баритполиметаллических месторождений порядком ниже кларковых значений для сфалеритов колчеданных руд, что свидетельствует о кислом характере среды рудообразования.

Также в этой ассоциации впервые был диагностирован (не был выявлен предшественниками) гринокит (в барит-полиметаллических рудах Стрижковского месторождения). Зерна размером 10..20 мкм с четкими и ровными контурами, располагающиеся на контакте барита и сфалерита II, а также в межзерновом пространстве агрегатов сфалерита.

В данной ассоциации присутствует и арсенопирит преимущественно в виде единичных идиоморфных короткостолбчатых зерен размером не более 30 мкм в тесной ассоциации с тетраэдритом и сфалеритом II.

Борнит-халькозиновая парагенетическая ассоииа ция (3 стадия минералообразования). Данная ассоциация представляет наибольший интерес ввиду развития в ней минералов благородных металлов, относящихся к группе редких, при этом и основные минералы данного комплекса в качестве изоморфной примеси, в довольно широких диапазонах, нередко содержат примеси серебра. Содержание золота и серебра в таких рудах, по данным атомно-абсорбционного анализа, варьирует в пределах: Au 8...30 г/т, Ag 50...800 г/т. Содержания серебра, как правило, в несколько раз превышают содержания золота, что является характерной чертой вулканогенных гидротермальных месторождений [24].

Борнит в образцах представлен отдельными зернами и зернистыми агрегатами (рис. 2, f), выполняющими прожилки, линзочки и гнезда размером $1 \ldots 8 \mathrm{~cm}$ в тесном срастании с теннантитом, реже встречаются каемки вокруг ранее выделившихся тетраэдрита и халькопирита I. Наибольшее распространение имеет на Зареченском месторождении, чуть меньшее на Змеиногорском, совсем в ограниченном количестве встречается на Стрижковском.

В свежем сколе имеет медно-красный цвет, на поверхности штуфных образцов борнит повсеместно покрыт пленкой яркой, преимущественно синего цвета, побежалости, благодаря чему довольно легко диагностируется в изучаемых образцах. Участками содержит микроскопические, пластинчатой формы включения халькопирита II. Зачастую содержит примесь серебра от $0 . .5$ мас. \%.

Халькозин по времени выделения весьма близок к борниту, образует сплошные тонкозернистые массы или единичные зерна размером до 2...4 мм. Участками наблюдается замещение зерен халькопирита I халькозином. В халькозине также довольно устойчиво отмечается примесь серебра $0,6 \ldots 3,8$ мас. \%.

Теннантит в виде стально-серого цвета отдельных зерен размером до 1 см или сплошных тонко- и мелкозернистых масс имеет четкие границы с борнитом, халькозином и халькопиритом II. Содержание примеси серебра до 4 мас. \%.

Как было сказано выше, наблюдается тенденция изменения состава блеклых руд от 2 к 3 стадии минералообразования и проявляется обратная корреляция между соотношениями $\mathrm{Sb} /(\mathrm{Sb}+\mathrm{As})$ и $\mathrm{Fe} /(\mathrm{Fe}+\mathrm{Zn})$, а также уменьшается массовая доля серебра в качестве изоморфной примеси от тетраэдрита к теннантиту (рис. 3).

При этом стоит отметить, что для блеклых руд изученных месторождений не характерно проявление какой-либо зональности, что обычно свойственно блеклым рудам вулканогенных типов месторождений [25]. Это можно объяснить, по-видимому, условиями формирования, а именно упорядоченностью процесса кристаллизации при постепенном снижении температуры рудообразующих растворов.

Отсутствие же теннантита на Стрижковском месторождении, вероятно, связано с уровнем эрозионного среза, который является максимальным относительно Змеиногорского и тем более Зареченского месторождений.

Пирит II зачастую образует агрегаты пирит-марказит, в виде колломорфных обособлений, с четко проявленным зональным строением. Такие агрегаты пирита II отмечаются в колчеданно-полиметаллических и полиметаллических типах руд и представляют собой фактически мономинеральные почки размером 0,2...60 мм, однако редко отмечаются сложные по строению и составу агрегаты, зональные, состоящие из чередующихся зонок пирита, сфалерита II и галенита II, реже между зонами пирита были отмечены обособления блеклых руд и в некоторых случаях кальцита. Появление пирита такой формы свидетельствует об образовании его в условиях резкого пресыщения рудообразующих растворов, которое происходит при смешении горячего восстановительного металлоносного флюида (с участием сульфатредуцирующих бактерий) с относительно холодной морской водой [26]. 

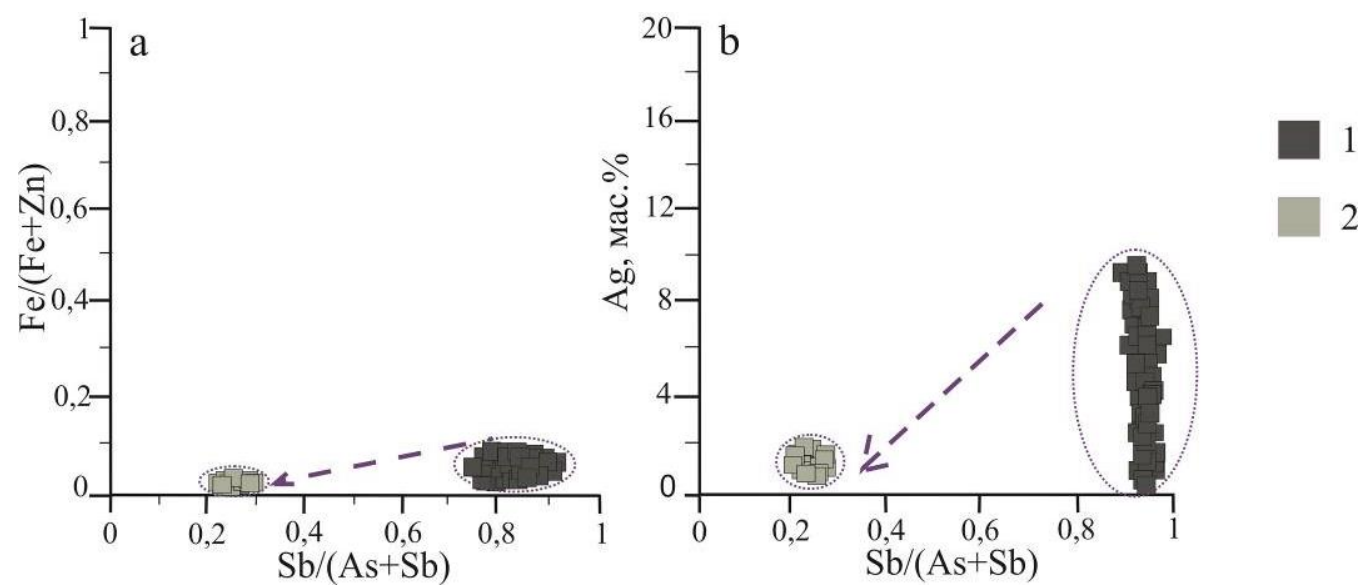

Pис. 3. Соотночение: a) $\mathrm{Fe} /(\mathrm{Fe}+\mathrm{Zn})$ к $\mathrm{Sb} /(\mathrm{Sb}+\mathrm{As})$, b) $\mathrm{Ag} \kappa \mathrm{Sb} /(\mathrm{Sb}+\mathrm{As})$ в блекльх рудах барит-полиметаллических месторождений Змеиногорского рудного района (Змеиногорского, Зареченского, Стрижковского), 1 - тетраэдрит, 2 - теннантит. Стрелками показана эволюччия состава блекльх руд от 2 стадии (более ранней, кристаллизачия тетраэдрита) к 3 стадии (более поздней, кристаллизация теннантита)

Fig. 3. Corellation of: a) $\mathrm{Fe} /(\mathrm{Fe}+\mathrm{Zn})$ to $\mathrm{Sb} /(\mathrm{Sb}+\mathrm{As})$, b) Ag to $\mathrm{Sb} /(\mathrm{Sb}+\mathrm{As})$ at fahlores of barite-polymetallic deposits of Zmeinogorsk ore district (Zmeinogorsk, Zarechensk, Strizhkovsk deposits), 1 - tetrahedrite, 2 - tennantite. Arrows show the evolution of the composition of fahlores from the $2^{\text {nd }}$ stage (earlier stage, crystallization of tetrahedrite) to the $3^{\text {rd }}$ stage (later stage, crystallization of tennantite)

Колломорфные формы пирита распространены и на вулканогенно-осадочных колчеданно-полиметаллических объектах Змеиногорского рудного района, например на Корбалихинском, Лазурском, Семеновском месторождениях [27], и нередко содержат примеси Tl, As, Sb и Pb [28]

Также в данной ассоциации отмечаются микроскопические выделения позднего галенита (галенит II), обособляющегося в виде тонких прожилков или изометричных образований размером до 3 мм. Содержание примеси серебра в галените до 2 мас. \%.

Редкие минераль. К редким минералам, диагностированным на изученных месторождениях, относятся: алтаит, штромейерит, гессит, ялпаит, акантит, самородное серебро, электрум, амальгамы золота и серебра.

Наибольшее распространение минералов этой группы отмечено в борнит-халькозиновой ассоциации, во всех типах изученных руд, и только акантит и самородное серебро отмечаются в галенитблекловорудной ассоциации, в полиметаллическом и барит-полиметаллическом типе руд.

Самородное серебро встречено на всех трех месторождениях (в существенно полиметаллических рудах либо в барит-полиметаллических), найдены обособленные тонкие листочки, дендритовидные выделения, а также выделения, находящиеся в тесном срастании с акантитом, на границе зерен халькопирита I с блеклыми рудами, либо нитевидные просечки в тетраэдрите. Для серебра Зареченского месторождения отмечаются примеси Мо и Те - до 0,3 и 0,4 \% соответственно. Акантит встречается довольно часто практически во всех типах руд, участками совместно с галенитом II, тетраэдритом, участками образует своеобразные зонально-кольцевые обособления, также встречается и в виде самостоятельных выделений, а также в виде «корочек» и «налета» на блеклых рудах и халькопирите I либо на границе зерен этих минералов.

Гессит встречается в существенно колчеданных типах руд, реже в полиметаллических, в виде неправиль- ной формы выделений размером до 100 мкм. Часто в тесной ассоциации с гесситом можно встретить выделения самородного теллура размером до $10 \ldots 15$ мкм, выявляются на контакте галенита I и барита, также среди агрегатов халькопирита I (рис. $4, a, b)$.

Амальгамы серебра и золота имеют локальное распространение и диагностированы пока только на Зареченском месторождении в борнит-халькозиновой ассоциации. Диагностированы как амальгаммы золота, так и амальгаммы серебра, также реже отмечаются смешанные золото+серебро. Выполняют прожилки, линзочки и гнезда размером до 100 мкм совместно с электрумом, штромейеритом, располагаясь в межзерновом пространстве халькозина, борнита и теннантита.

Электрум в виде округлых (рис. 4, c) или неправильной формы обособлений, а также в виде тонких просечек размером 2...15 мкм в виде механической примеси в халькозине или на контактах зерен борнита, халькозина и блеклой руды, реже в межзерновом пространстве барита. Тесная связь золота и блеклых руд, а также халькозина и борнита не раз подчеркивалась многими исследователями на разных золоторудных объектах мира [29].

Штромейерит и ялпаит зачастую выполняют микроскопические прожилки или неправильной формы обособления размером до 50..70 мкм в сфалерите II, теннантите и барите.

К 4 стадии минералообразования относится $б a$ рит-кальичит-гематитовая ассоцииция.

Минералы данной ассоциации формируют жилы, прожилки, гнезда, а также вкрапления.

Барит наиболее распространенный жильный минерал в данной ассоциации, на долю которого, в зависимости от типа руд, отводится вплоть до 80 \% (барит-полиметаллический тип). Зачастую образует зернистые агрегаты в виде шлировых обособлений и гнезд, иногда отмечаются идиоморфные столбчатые зерна размером 0,3...10 мм, в интерстициях которых участками обособлены сульфиды. 

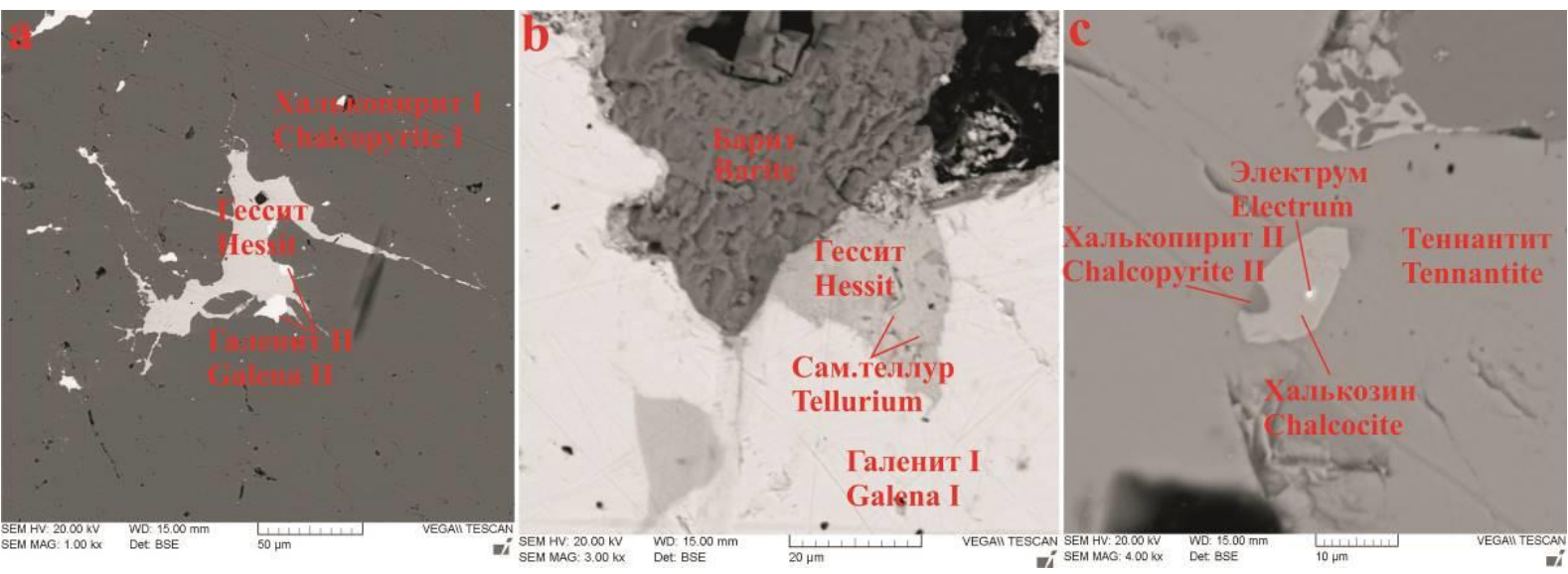

Рис. 4. Обособления редких минералов в барит-полиметаллиеских рудах: а) неправильной формы обособление гессита и галенита II в агрегате халькопирита I (Зареченское месторождение); b) обособления гессита и самородного теллура на контакте зернистого агрегата барит и галенита (Стрижковское месторождение); c) обособление округлой формы электрума (Au-65\%, $\mathrm{Ag}-35$ \%) в зерне халькозина в общей массе теннантита (Зареченское месторождение)

Fig. 4. Segregation of rare minerals at barite-polymetalic ores: a) irregular segregation of hessite and galena II in the chalcopyrite I aggregate (Zarechensk deposit); b) segregation of hessite and native tellurium at the contact of the granular aggregate of barite and galena (Strizhkovsk deposit); c) segregation of the rounded shape of electrum (Au - $65 \%$, $A g-35 \%)$ in the grain of chalcocite in the total mass of tennantite (Zarechensk deposit)

В качестве примесных элементов составе барита содержатся Сo $(0,1 \ldots 0,2$ мас. \%) и $\mathrm{Sr}(0,2 \ldots 1,3$ мас. \%)

Не исключено и выделение более позднего «чистого» барита, формирующего мономинеральные шапки на Стрижковском и Змеиногорском месторождениях.

Кальиичт образует прожилки, разбивая ранее выделившиеся минералы, в основном сульфиды, находится в тесной ассоциации с кварцем, реже с баритом. Размер отдельных зерен не превышает $0,1 \ldots 5$ мм. Отмечается примесь марганца $0,35 \ldots 0,7$ мас. \%.

Гематит имеет наименьшее распространение, отмечается в виде прожилков между кварцем и ранее кристаллизовавшимися сульфидами, а также в тесной ассоциации с баритом, придавая последнему зачастую розоватую окраску.

\section{Изучение изотопов серы}

Изотопный состав серы сульфидных минералов гидротермальных месторождений зависит от источника серы гидротермальных растворов и физикохимических условий кристаллизации сульфидных минералов [30].

Для изотопных характеристик изучаемых месторождений были отобраны монофракции сульфидов из каждой выделенной парагенетической ассоциации (табл. 2). Стоит отметить, что в целом сульфиды изученных гидротермальных барит-полиметаллических месторождений имеют несколько облегченный изотопный состав, в то время как большинство объектов колчеданной формации Казахстанского и Уральского регионов характеризуются устойчивым утяжеленным составом [31].

Таким образом, сульфиды первой стадии по своим значениям $(0 \ldots+1,2 \%)$ соответствуют мантийным меткам $[32,33]$, сульфиды второй стадии $(-2,3 \ldots-3,7 \%)$ близки к коровым значениям, сульфиды третьей стадии имеют совсем облегченный состав (до - 12,8 \%о) (табл. 2).
Полученные данные хорошо соотносятся с данными подобных объектов мира [34], что говорит о том, что руды данных объектов принадлежат к определенному известному формационному типу.

Таблица 2. Вариации средних значений изотопов серы основных сульфидов выделенных парагенези$\mathrm{COB}$

Table 2. Variations of basic sulfide sulfur isotope average values in subtracted paragenetic association

\begin{tabular}{|c|c|c|c|}
\hline $\begin{array}{c}\text { Минерал } \\
\text { Mineral }\end{array}$ & $\begin{array}{c}\text { Характерные структуры } \\
\text { и текстуры } \\
\text { Characteristic structures and } \\
\text { textures }\end{array}$ & 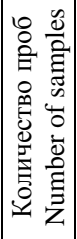 & 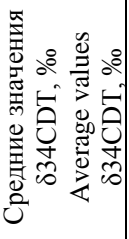 \\
\hline \multicolumn{4}{|c|}{ Сульфиды I стадии/Sulfides of the first stage } \\
\hline $\begin{array}{l}\text { Пирит } \\
\text { Pyrites }\end{array}$ & \multirow{3}{*}{$\begin{array}{l}\text { Прожилковая, вкрапленная, } \\
\text { прожилково-вкрапленная, } \\
\text { брекчиевая; раздробленная, } \\
\text { распада твердых растворов, за- } \\
\text { мещения } \\
\text { Vein texture, impregnated, vein- } \\
\text { impregnated, breccia, corrugated, } \\
\text { disproportional, replacement }\end{array}$} & 6 & $-0,2$ \\
\hline $\begin{array}{l}\text { Халькопирит } \\
\text { Chalcopyrite }\end{array}$ & & 5 & 0 \\
\hline $\begin{array}{l}\text { Сфалерит I } \\
\text { Sphalerite I }\end{array}$ & & 5 & $+1,2$ \\
\hline \multicolumn{4}{|c|}{ Сульфиды II стадии/Sulfides of the second stage } \\
\hline $\begin{array}{l}\text { Галенит } \\
\text { Galena }\end{array}$ & \multirow{3}{*}{$\begin{array}{l}\text { Массивная, гнездовая, прожил- } \\
\text { ковая, мелко-, среднезернистая, } \\
\text { аллотриоморфно-зернистая, пе- } \\
\text { тельчатая } \\
\text { Massive, pockety segregation, } \\
\text { vein texture, micro-, mediun grain } \\
\text { structure, allotriomorphic- } \\
\text { granular, reticulate }\end{array}$} & 6 & $-3,4$ \\
\hline $\begin{array}{l}\text { Сфалерит II } \\
\text { Sphalerite II }\end{array}$ & & 5 & $-2,3$ \\
\hline $\begin{array}{l}\text { Тетраэдрит } \\
\text { Tetrahedrite }\end{array}$ & & 5 & $-3,7$ \\
\hline \multicolumn{4}{|c|}{ Сульфиды III стадии/Sulfides of the third stage } \\
\hline $\begin{array}{l}\text { Борнит } \\
\text { Bornite } \\
\end{array}$ & \multirow{2}{*}{$\begin{array}{l}\text { Прожилковая, вкрапленная, } \\
\text { гнездовая, замещения } \\
\text { Vein texture, impregnated, } \\
\text { pockety segregation, replacement }\end{array}$} & 2 & $-8,9$ \\
\hline $\begin{array}{l}\text { Теннантит } \\
\text { Tennantite }\end{array}$ & & 2 & $-12,8$ \\
\hline
\end{tabular}


Столь большие отрицательные значения $\delta^{34} \mathrm{~S}$ в борните и теннантите могут быть объяснены частичным окислением сульфидной серы рудного раствора или же флюида, происходящем при повышении окислительного потенциала. В результате чего происходит разделение изотопов между окислительными и восстановительными формами серы, при этом восстановительные формы обогащаются легким изотопом $\mathrm{S}^{32}$. В таких случаях рудный процесс заканчивается, как правило, отложением гипогенных сульфатов, как и в случае изученных барит-полиметаллических месторождений, а именно отложением барита [35].

\section{Заключение}

Проведенные исследования первичных руд баритполиметаллических месторождений Змеиногрского рудного района позволили сделать основные выводы:

1. Изученные месторождения по своему генетическому типу являются средне-, низкотемпературными, относящимися к вулканогенногидротермальному типу, сформировавшимися в условиях умеренных глубин, являющимися продуктами поствулканической гидротермальной деятельности эмсского вулканизма существенно кислой направленности.

2. Тектонические зоны месторождений многократно активизировались и сопровождались синхронными дискретными вспышками рудогенеза, поэтому барит-полиметаллическое оруденение района имеет многостадийный характер, подтвержденный не только минераграфическими исследованиями, но и изменяющимися изотопными характеристиками.

3. Сложный механизм формирования руд месторождений подчеркивается разнообразием минераль-

\section{СПИСОК ЛИТЕРАТУРЫ}

1. Контарь Е.С. Месторождения свинца и цинка в истории формирования земной коры // Литосфера. - 2016. - № 3. - С. 5-26.

2. Серавина Т.В., Кузнецов В.В., Конкина А.А. Золотосеребросодержащие полиметаллические месторождения технология и опыт их прогноза и поисков // Известия Тульского государственного университета. Науки о Земле. 2020. - № 1. - С. 303-314.

3. Дергачев А.Л. Глобальные факторы свинцово-цинкового рудообразования // Вестник Московского государственного университета. - 2019. - Т. 4. - № 4. - С. 3-10.

4. Основы прогноза и поисков колчеданно-полиметаллических месторождений Рудного Алтая / В.В. Кузнецов, Н.Г. Кудрявцева, Т.В. Серавина, О.В. Мурзин, Д.А. Корчагина, С.В. Кузнецова, С.А. Миляев. - М.: ЦНИГРИ, 2019. - 208 с.

5. Гринев О.М. Историческая ретроспектива и потенциал месторождений Рудного Алтая как источника золота и серебра // Петрология магматических и метаморфических комплексов: Материалы третьей ежегодной научной конференции. - Томск: Томский Государственный Университет, 2002. - Т. II. - С. 44-58.

6. Чекалин В.М. К вопросу о зональности и генезисе Зареченского барит-полиметаллического месторождения на Рудном Алтае // Геология и металлогения северо-западной части Рудного Алтая. - Томск: Изд-во Томского политехнического университета, 2016. - С. 245-249.

7. Гаськов И.В.Особенности эндогенной металлогении Горного и Рудного Алтая (Россия) // Геология и геофизика. - 2018. Т. 59. - № 8. - С. 1254-1270.

8. Гринев О.М., Бестемьянова К.В., Гринев Р.О. Морфоструктуры и вещественный состав эмс-раннеэйфельских вулканитов Змеиногорского рудного района (Рудный Алтай) // Петроло- ного состава, в том числе и сочетанием присутствующих минеральных форм, образующихся в эволюционирующих физико-химических и фациальных условиях рудоотложения.

4. Околорудные метасоматиты и продукты установленных стадий минерализации последовательно формировались в рудных этапах, зачастую телескопированно накладываясь друг на друга и усложняя минералогический состав рудных тел. Выделены обобщенные для трех изученных месторождений парагенетические ассоциации, соответствующие последовательно сменяющим друг друга стадиям минералообразования, от ранних к поздним: пирит-сфалерит-халькопиритовая $\rightarrow$ галенит-блекловорудная $\rightarrow$ борнит-халькозиновая $\rightarrow$ барит-кальцит-гематитовая. При этом наиболее продуктивной стадией, в течение которой отлагалась наибольшая часть благороднометалльной минерализации, является третья с борнитхалькозиновой ассоциацией.

5. Для изученных барит-полиметаллических месторождений характерен комбинированный источник серы. Изменение значений $\delta^{34} \mathrm{~S}$ от начальных стадий к конечным, от утяжеленных меток к облегченным, демонстрирует заметное фракционирование изотопов серы в рудном процессе и указывает на гетерогенный источник. С этим согласуются и выводы по гетерогенному источнику вулканитов, а именно плюмовому и субдукционному, установленному ранее проведенными исследованиями [8].

Работа выполнена в рамках государственного задания Министерства науки и выстего образования РФ № 07212020-0041.

гия магматических и метаморфических комплексов: Материалы IX Всероссийской конференции с международным участием. - Томск: Томский государственный университет, 2017. C. $118-127$.

9. Ворошилов В.Г., Понитевский К.Л. Геохимическая зональность колчеданно-полиметаллических месторождений северозападной части Рудного Алтая // Известия Томского политехнического университета. - 2001. - Т. 304. - № 1. - С. 160-169.

10. Маслеников В.В. Вулканизм и рудообразование - генетические проблемы // Металлогения древних и современных океанов. - 2018. - № 1. - С. 13-18.

11. Викентьев И.В. Условия формирования и метаморфизм колчеданных руд. - М.: Изд-во «Научный мир», 2004. - 340 с.

12. Зайков В.В. Вулканизм и сульфидные холмы палеоокеанических окраин. - М.: Изд-во «Наука», 2006. -429 с.

13. Серавина Т.В. Положение колчеданно-полиметаллических месторождений Сибири в вулканогенном разрезе (на примере Рудноалтайской, Салаирской, Кызыл-Таштыгской и Приаргунской минерагенических зон // Металлогения древних и современных океанов. - 2018. - № 1. - С. -104-108.

14. Серавкин И.Б., Косарев А.М. Южный Урал и Рудный Алтай: сравнительный палеовулканический и металлогенический анализ // Геология рудных месторождений. - 2019. - Т. 61. № 2. - C. 3-22.

15. Бестемьянова К.В., Гринев О.М. Околорудные метасоматиты барит-полиметаллических месторождений Змеиногорского рудного района (Рудный Алтай) // Известия Томского политехнического университета. Инжиниринг георесурсов. 2017. - T. 328. - № 9. - C. 114-126.

16. Bozkaya G., Banks D.A. Sulfur isotope geochemistry and mineralogy of Bacilar vein type barite-sulphide mineralization, 
Biga peninsula, NW Turkey // Pamukale University Muhendislik Bilimerli Dergisi. - 2016. - V. 22 (3). - P. 200-205.

17. Sulfur isotope variation in volcanic-associated massive sulfides of the Northern Appennine ophiolites (Italy) / G. Garuti, F. Zaccarini, P. Alfonso, J.A Proenza. // Mafic-ultramafic complexes of folded regions and related deposits: the third international conference. Kachkanar: Institute of Geology and Geochemistry UB RAS, 2009. - P. 12-16.

18. Дергачев А.Л., Еремин Н.И., Сергеева Н.Е. Разномасштабные тенденции в эволюции состава руд вулканогенных колчеданных месторождений // Вестник Московского государственного университета. - 2013. - Т. 4. - № 5. - С. 31-40.

19. Дергачев А.Л., Еремин Н.И. Вулканогенные колчеданные месторождения богатых золотом руд // Вестник Московского государственного университета. - 2018. - Т. 4. - № 3. - С. 3-11.

20. Reed S.J.B. Electron microprobe analysis and scanning electron microscopy in geology. - N.Y.: Cambridge University Press, 2005. $-189 \mathrm{p}$.

21. Reed M.H., Palandri J. Sulfide mineral precipitation from hydrothermal fluids // Reviews in Mineralogy and Geochemistry. - 2006. - V. 61. - № 1. - P. 609-631.

22. Prieto M. Thermodynamics of solid solution-aqueous solution systems // Reviews in Mineralogy and Geochemistry. - 2009. V. 70. - № 1. - P. 47-85.

23. Putnis A. Mineral replacement reactions // Reviews in mineralogy and geochemistry. - 2009. - V. 70. - № 1. - P. 87-124.

24. Gold and silver in ores of volcanogenic hydrothermal and hydrothermal-sedimentary pyrite-polymetallic deposits of Siberia / K.R. Kovalev, E.G. Distanov, G.N. Anoshin, I.V. Gas'kov, V.A. Akimtsev, M.V. Baulina // Geology and Geohysics. 2004. - V. 45. - № 10. - P. 1121-1135.

25. Chemical composition and varieties of fahlore-group minerals from Oligocene mineralization in the Rhodope area, Southern Bulgaria and Northern Greece / A. Repstock, P. Voudouris,
M. Zeug, V. Melfos, M. Zhai, H. Li, J. Matuszczak // Mineralogy and Petrology. - 2016. - V. 110. - № 1. - P. 103-123.

26. Skarpelis N. Settings, sulfur isotope variations, and metamorphism of Jurassic massive $\mathrm{Zn}-\mathrm{Pb}-\mathrm{Ag}$ sulfide mineralization associated with arc-type volcanism (Skra, Vardar zone, Nothern Greece) // Resource Geology. - 2020. - V. 70. - № 4. - P. 311-335.

27. Кузнецова С.В. Некоторые вопросы генезиса и минералогические особенности стратиформных руд колчеданнополиметаллических месторождений Рудного Алтая, Алтайский край // Руды и металлы. - 2017. - № 2. - С. 40-50.

28. Маслеников В.В. Четверть века развития и достижений теории литогенеза колчеданных месторождений // Металлогения древних и современных океанов. - 2019. - № 1. - С. -5-10.

29. Zhou J., Jago B., Martin C. Establishing the process mineralogy of gold ores // SGS Minerals Technical Bull. - 2004. - V. 3. - P. 1-16.

30. Seal R.R. Sulfur isotope geochemistry of sulfide minerals // Mineralogy and Geochemistry. - 2006. - V. 61. - P. 633-677.

31. Дистанов Э.Г. Изотопные исследования процессов рудообразования. - Новосибирск: Изд-во «Наука», 1991. - 204 с.

32. Ohmoto H., Rye R.O. Isotopes of sulfur and carbon // Geochemistry of hydrothermal ore deposits. - N.Y.: John Wiley and Sons, 1979. - P. 509-567.

33. Ohmoto H. Stable isotope geochemistry of ore deposits // Review Mineralogy. - 1986. - V. 16. - P. 491-560.

34. Hoefs J. Stable isotope geochemistry. - Berlin; Heidelberg: Springer-Verlag, 2009. $-281 \mathrm{p}$.

35. Origin of a barite-sulfide ore deposit in the Mykonos intrusion, cyclades: trace element, isotopic, fluid inclusion and raman spectroscopy evidence / S.F. Tombros, K.St. Seymour, A.E. Williams-Jones, D. Zhai, J. Liu // Ore Geology Reviews. 2015. - V. 67. - P. 139-157.

Поступила 25.08.2021 г.

\section{Информация об авторах}

Бестемьянова К.B., младший научный сотрудник лаборатории геохронологии и геодинамики, ассистент кафедры минералогии и геохимии Геолого-географического факультета Национального исследовательского Томского государственного университета.

Гринев О.М., кандидат геолого-минералогических наук, доцент кафедры палеонтологии и исторической геологии Геолого-географического факультета Национального исследовательского Томского государственного университета. 
UDC 549.32/.33:553.412'44

\title{
MINERALOGY OF BARITE-POLYMETALLIC DEPOSITS OF ZMEINOGORSK ORE DISTRICT (RUDNY ALTAI)
}

\author{
Ksenia V. Bestemianova ${ }^{1}$, \\ KsenijaVT@mail.ru \\ Oleg M. Grinev 1 , \\ tomskgrom@yandex.ru \\ 1 National Research Tomsk State University, \\ 36, Lenin avenue Tomsk, 634050, Russia.
}

Relevance of the research is conditioned by a need to understand the formation model of studied ore deposits; this leads to development of scientifically valid prediction and estimation and, hence, expansion of available mineral resources (first of all, copper, lead and zinc ores) while continuous prospecting and exploration at Rudny Altai including deeper and side zones of known deposits.

The main aim is to study ore mineral composition with use of advanced analytical techniques, mineral and geochemical features and formation processes of barite-polymetallic ore deposits of Zmeinogorsk district.

Research methods are represented by a complex study of barite-polymetallic ores including polarization microscopy, energy dispersive $X$-ray microanalysis of ores and separate sulfides, inductively coupled plasma mass spectrometry (ICP-MS) and atomic absorption spectrometry.

The results. Mineralogical composition of barite-polymetallic ores of Zmeinogorsk district deposits has been studied. It includes about 30 minerals, among which are (in descending order) sulfides, sulfosalts, tellurides, oxides, oxyacid salts, native elements and intermetallics. Ore bodies are represented by complex stockworks, band- and lens-shaped bodies with ores belonging to following types (from bottom to top): pyrite-polymetallic, polymetallic and barite-polymetallic ores. Hydrothermal and metasomatic processes preceded ore formation leading to formation of wallrock non-carbonate metasomatites. It was stated that the third stage of mineral formation (bornite-chalcocite association) was the most productive in terms of own mineral phases of precious metals. According to the results of sulfur isotopic composition study in sulfides there was a heterogeneous source of ore material: initial mantle source was later changed by a crustal source. Isotopic composition of first stage sulfides ( $\delta 34 S$ ) varies from $-0,2$ to $+1,2 \%$; from $-2,3$ to $-3,7 \%$ in second stage sulfides; from $-8,9$ to $-12,8 \%$ o in third stage sulfides.

Key words:

Zmeinogorsk ore district, barite-polymetalic ores, stages, paragenetic assemblage, sulfur isotopic compositions.

The research was carried out with the support of the Ministry of Science and Higher Education of the Russian Federation within the framework of the state assignment (project no. 0721-2020-0041).

\section{REFERENCES}

1. Kontar E.S. Lead and zinc deposits in forming history of the Eart's crust. Lithosphere, 2016, no. 3, pp. 5-26. In Rus.

2. Seravina T.V., Kuznetsov V.V., Konkina A.A. Gold-silvercontaining polymetallic deposits - technology and experience of their forecasting and prospecting. Bulletin of the Tula State University, 2020, no. 1, pp. 303-314. In Rus.

3. Dergachev A.L. Global factors of lead-zinc ore formation. Mos cow University Bulletin, 2019, vol. 4, no. 4. pp. 3-10. In Rus.

4. Kuznetsov V.V., Kudravceva N.G., Seravina T.V., Murzin O.V., Korchagina D.A., Kuznetcova S.V., Miliaev S.A. Osnovy prognoza $i$ poiskov kolchedanno-polimetallicheskikh mestorozhdeniy Rudnogo Altaya [The foundation of forecasting and prospecting for pyrite-polymetallic deposits of Rudny Altai]. Moscow, TsNIGRI, 2019. $208 \mathrm{p}$.

5. Grinev O.M. Istoricheskaya retrospektiva i potentsial mestorozhdeniy Rudnogo Altaya kak istochnika zolota i serebra [Historical retrospective and potential of the Rudny Altai deposits as a source of gold and silver]. Materialy tretyey ezhegodnoy nauchnoy konferentsii. Petrologiya magmaticheskikh i metamorficheskikh kompleksov [Materials of the third annual scientific conference. Petrology of magmatic and metamorphic complexes]. Tomsk, Tomsk State University Publ., 2002. pp. 44-58.

6. Chekalin V.M. K voprosu o zonalnosti i genezise Zarechenskogo barit-polimetallicheskogo mestorozhdeniya na Rudnom Altaye [On the issue of zoning and genesis of the Zarechensky baritepolymetallic deposit at Rudny Altai]. Geologiya $i$ metallogeniya severo-zapadnoy chasti Rudnogo Altaya [Geology and metallogeny of the northwestern part of Rudny Altai]. Tomsk, Tomsk Polytechnic University Publ., 2016. pp. 245-249.
7. Gaskov I.V. Features of magmatism-related metallogeny of Gorny Altai and Rudny Altai (Russia). Geology and geophysics, 2018, vol. 59, no. 8, pp. 1254-1270. In Rus.

8. Grinev O.M., Bestemianova K.V., Grinev R.O. Morfostruktury i veshchestvenny sostav ems-ranneefelskikh vulkanitov Zmeinogorskogo rudnogo rayona (Rudny Altay) [Morphostructures and material composition of the Ems-Early Eifel volcanics of the Zmeinogorsk ore region (Rudny Altai)]. Petrologiya magmaticheskikh $i$ metamorficheskikh kompleksov. Materialy IX Vserossiyskoy konferentsii s mezhdunarodnym uchastiyem [Petrology of magmatic and metamorphic complexes. Materials of the IX All-Russian conference with international participation]. Tomsk, Tomsk State University Publ., 2017. pp. 118-127.

9. Voroshilov V.G., Ponitevskii K.L. Geochemical zoning of pyritepolymetallic deposits in the northwestern part of Rudny Altai. Bulletin of the Tomsk Polytechnic University, 2001, vol. 304, no. 1, pp. 160-169.

10. Maslennikov V.V. Vulkanizm i rudoobrazovanie - geneticheskie problemy [Volcanism and ore formation - genetic issues]. Metallogeniya drevnikh i sovremennykh okeanov, 2018, no. 1, pp. 13-18.

11. Vikentev I.V. Usloviya formirovaniya $i$ metamorfizm kolchedannykh rud [Conditions formation and metamorphism of pyrite ores]. Moscow, Naucnu mir Publ., 2004. 340 p.

12. Zaikov V.V. Vulkanizm i sulfidnye kholmy paleookeanicheskikh okrain [Volcanism and sulfide hills of the paleoceanic margins]. Moscow, Nauka Publ., 2004. 340 p.

13. Seravina T.V. Polozhenie kolchedanno-polimetallicheskikh mestorozhdeniy Sibiri v vulkanogennom razreze (na primere Rudnoaltayskoy, Salairskoy, Kyzyl-Tashtygskoy i Priargunskoy mineragenicheskikh zon) [The position of the pyrite-polymetallic de- 
posits of Siberia in the volcanic section (on the example of the Rudnoaltaiskaya, Salairskaya, Kyzyl-Tashtygskaya and Priargunskaya mineragenic zone)]. Metallogeniya drevnikh $i$ sovremennykh okeanov, 2018, no. 1, pp. 104-108.

14. Seravkin I.B., Kosarev A.M. South Urals and Rudny Altai: a comparative paleovolcanic and metallogenic analysis. Geology of Ore deposits, 2019, vol. 61, no. 2, pp. 3-22. In Rus.

15. Bestemianova K.V., Grinev O.M. Wallrock metasomatites of barite-polymetallic deposits of Zmeinogorsk ore district (Rudny Altai). Bulletin of the Tomsk Polytechnic University. Geo Assets Engineering, 2017, vol. 328, no. 9, pp. 114-126. In Rus.

16. Bozkaya G., Banks D.A. Sulfur isotope geochemistry and mineralogy of Bacilar vein type barite-sulphide mineralization, Biga peninsula, NW Turkey. Pamukale University Muhendislik Bilimerli Dergisi, 2016, vol. 22 (3), pp. 200-205.

17. Garuti G., Zaccarini F., Alfonso P., Proenza J.A. Sulfur isotope variation in volcanic-associated massive sulfides of the Northern Appennine ophiolites (Italy). Mafic-ultramafic complexes of folded regions and related deposits: the third international conference. Kachkanar, Institute of Geology and Geochemistry UB RAS Publ., 2009. pp. 12-16.

18. Dergachev A.L. Different scale tendencies of the evolutions of the compositions of volcanogenic pyrite deposits ores. Moscow University Bulletin, 2013, vol. 4, no. 5, pp. 31-40. In Rus.

19. Dergachev A.L. Volcanogenic massive sulfide deposits enriched in gold. Moscow University Bulletin, 2018, vol. 4, no. 3, pp. 3-11. In Rus.

20. Reed S.J.B. Electron microprobe analysis and scanning electron microscopy in geology. N.Y., Cambridge University Press, 2005. $189 \mathrm{p}$.

21. Reed M.H., Palandri J. Sulfide mineral precipitation from hydrothermal fluids. Reviews in Mineralogy and Geochemistry, 2006, vol. 10, no. 1, pp. 609-631.

22. Prieto M. Thermodynamics of solid solution-aqueous solution systems. Reviews in Mineralogy and Geochemistry, 2009, vol. 70, no. 1, pp. 47-85.

23. Putnis A. Mineral replacement reactions. Reviews in mineralogy and geochemistry, 2009, vol. 10, no. 1, pp. 87-124.

24. Kovalev K.R., Distanov E.G., Anoshin G.N., Gaskov I.V., Akimtsev V.A., Baulina M.V. Gold and silver in ores of volcanogenic hydrothermal and hydrothermal-sedimentary pyrite- polymetallic deposits of Siberia. Geology and Geohysics, 2004, vol. 45, no. 10, pp. 1121-1135.

25. Repstock A., Voudouris P., Zeug M., Melfos V., Zhai M., Li H., Matuszczak J. Chemical composition and varieties of fahloregroup minerals from Oligocene mineralization in the Rhodope area, Southern Bulgaria and Northern Greece. Mineralogy and Petrology, 2016, vol. 110, no. 1, pp. 103-123.

26. Skarpelis N. Settings, sulfur isotope variations, and metamorphism of Jurassic massive $\mathrm{Zn}-\mathrm{Pb}-\mathrm{Ag}$ sulfide mineralization associated with arc-type volcanism (Skra, Vardar zone, Nothern Greece). Resource Geology, 2020, vol. 70, no. 4, pp. 311-335.

27. Kuznetsova S.V. Some issues of genesis and mineralogical features of stratiform ores of pyrite polymetallic deposits from Rudny Altai, Altai territory. Ores and metals, 2017, no. 2, pp. 40-50. In Rus.

28. Maslennikov V.V. Chetvert veka razvitiya i dostizheniy teorii litogeneza kolchedannykh mestorozhdeniy [A quarter of a century of development and achievements of the theory of lithogenesis of pyrite deposits]. Metallogeniya drevnikh i sovremennykh okeanov, 2019, no. 1, pp. 5-10.

29. Zhou J., Jago B., Martin C. Establishing the process mineralogy of gold ores. Minerals Technical Bull, 2004, vol. 3, pp. 1-16.

30. Seal R.R. Sulfur isotope geochemistry of sulfide minerals. Mineralogy and Geochemistry, 2006, vol. 61, pp. 633-677.

31. Distanov E.G. Izotopnye issledovaniya protsessov rudoobrazovaniya [Isotope studies of ore formation processes]. Novosibirsk, Nauka Publ., 1991. 204 p.

32. Ohmoto H., Rye R.O. Isotopes of sulfur and carbon. Geochemistry of hydrothermal ore deposits. N.Y., John Wiley and Sons, 1979. pp. 509-567.

33. Ohmoto H. Stable isotope geochemistry of ore deposits. Review Mineralogy, 1986, vol. 16, pp. 491-560.

34. Hoefs J. Stable isotope geochemistry. Berlin; Heidelberg, Springer-Verlag, 2009. $281 \mathrm{p}$.

35. Tombros S.F., Seymour K.St., Williams-Jones A.E., Zhai D., Liu J. Origin of a barite-sulfide ore deposit in the Mykonos intrusion, cyclades: trace element, isotopic, fluid inclusion and raman spectroscopy evidence. Ore Geology Reviews, 2015, vol. 67, pp. 139-157.

Received: 25 August 2021.

\section{Information about the authors}

Ksenia V. Bestemianova, junior researcher, assistant, National Research Tomsk State University.

Oleg M. Grinev, Cand. Sc., associate professor, National Research Tomsk State University. 